\title{
Analysis of the implementation of policies on the development of Indonesian migrant workers' families in the field of economic empowerment in Kupang city
}

Elisabeth Welin' ${ }^{1}$, Petrus Kase ${ }^{2}$, Nursalam Nursalam ${ }^{3}$

Public Administration Study Program, Nusa Cendana University, Kupang, Indonesia ${ }^{1,2,3}$

welin.elisabeth17@gmail.com

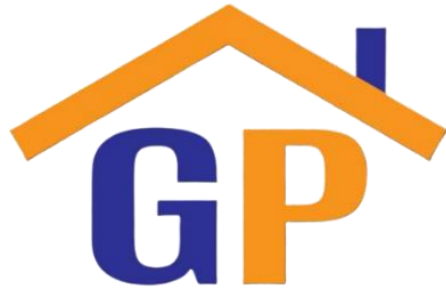

Article History

Received on 6 August 2020

$1^{\text {st }}$ Revision on 14 August 2020

$2^{\text {nd }}$ Revision on 23 February 2021

$3^{\text {rd }}$ Revision on 6 March 2021

Accepted on 10 March 2021

\begin{abstract}
Purpose: This research aims to analyze the implementation of policies on developing Indonesian migrant workers' families in the field of economic empowerment in Kupang city.
\end{abstract}

Research methodology: The method used in this research is a qualitative research method with a case study approach.

Results: The implementation of the family empowerment program for Indonesian workers is going well. This is supported by the existence of good communication, the availability of information and human resources, the influence of the position, and organizational arrangements to run the program in accordance with the SOP.

Limitations: This research only analyzes the implementation of policies on the development of Indonesian migrant workers' families in the field of economic empowerment in Kupang city.

Contribution: This research becomes scientific information for public administration science.

Keywords: Indonesian migrant workers, Policy, Empowerment

How to cite: Welin, E., Kase, P., \& Nursalam, N. 2021. Analysis of the implementation of policies on the development of Indonesian migrant workers' families in the field of economic empowerment in Kupang city. Dynamics of Politics and Democracy, 1(1), 49-61.

\section{Introduction}

Every family has the right to get protection to maintain wholeness, resilience, welfare and quality family based on a legal marriage and is characterized by being prosperous, healthy, advanced, independent, having an ideal number of children, forward-looking, responsible, harmonious and devoted to God Almighty. Likewise, the families of Indonesian Migrant Workers (TKI) whose family members work abroad are also entitled to their rights.

In order to fulfill the rights of the family in accordance with article 47 of Law 52 of 2009 concerning Population Development and Family Development requires the government and regional governments to set obligations through fostering the resilience of family welfare, among others by means of family empowerment and improving the quality of children.

Regulation of the Minister of Women's Empowerment and Child Protection No. 20 of 2010, outlining that the Government Policy to facilitate the placement of workers abroad is one of the efforts to overcome or eliminate unemployment. On the other hand, it is undeniable that even though sending Indonesian workers abroad provides a large additional foreign exchange for the country, it creates other problems, especially with abandoned families, for example, the inability of family members to manage remittances from overseas, there is a rift between husband and husband wives and children who are left behind are not fostered well. According to the Ministry of Manpower and 
Transmigration, the placement of TKI overseas was 2,679,536 people, while foreign exchange receipts from remittances sent by TKI until the end of 2009 reached the US \$ 6,615,321,274 billion.

The number of migrant workers is increasing due to economic and social aspects. The decision of a person to become a migrant worker abroad is influenced by the number of family members who are dependent and the number of children, skills and work, and the average income before working abroad. Information factors from someone who has worked abroad about success, high income, and the lure of high income while abroad are the main driving factors for working abroad, in addition to the factors of age, sex, marital status, education level, the status of migrant workers in the family, and the people who influence the decision to work abroad also provide a background for a person's choice of working abroad.

Migrant workers who already have marital status have their own problems in the relationship between husband and wife and their children. Communication between migrant workers and their families cannot be done directly and is limited because there are constraints of distance, time, and cost, and is influenced by the employer where they work. These things certainly affect the harmony of the family as well as in childcare patterns.

Indonesian Migrant Workers family household problems related to fulfilling sexual/biological needs between husband and wife can result in family disharmony and even divorce, as well as neglect of the children of migrant workers' families and finally, the performance of migrant workers' children decreases, easily affected by negative actions, for example gambling smoking and drinking. Based on the background above, the authors designed a study with the title: Analysis of the Implementation of Policies on the Development of the Family of Indonesian Workers (BKTKI) in the Field of Economic Empowerment in Kupang City.

\section{Literature review}

\section{Public policy}

The concepts of "public policy" and "government policies" are similar. According to Friedrich (1969), a policy is a set of actions suggested by someone, a party, a government, or an environment to demonstrate the opportunities and constraints to enforcing the proposed policy in order to accomplish those goals. Meanwhile, Thomas R. Dye describes the public policy as "whatever Governments want to do or not to do." "Public policy" includes what the government does, as well as what it does not do. Meanwhile, according to David Easton, public policy is described as "allocating values to the general population" (Mulyadi, 2016: 36).

According to Friedrich (1969: 79), the policy is all that affects or influences the general population or general well-being in a given jurisdiction, and the capacity of government to serve and protect its people and fulfill its duties to the general public (usually defined as its duties to serve and protect the general public) "a set of actions/activities that an individual, party propose, or government in a certain environment where there are obstacles and opportunities where the policy is being considered for implementation in order to resolve the difficulties and exploit the opportunities to achieve the desired objectives Public policymaking is described by Anderson (1984:3) as follows: "a set of activities with a particular aim or objective is conducted by actors or a group of actors that are closely associated with an issue that must be noticed. This definition of a policy focuses on current practices instead of ideas or intentions.

Mulyadi (2016: 37) believes that public policy is a decision taken to overcome errors in carrying out operations or accomplish certain objectives achieved by government agencies who have the Authority to carry out tasks for the good of the state in one policy. Public problems can be divided into procedural problems, which relate to how the government is organized and how the government performs its duties. By looking at this definition, the understanding of public policy can be concluded into two divisions. The first division of public policy types is what the government decides to do or leave behind. The second division of types of public policy is its form. Furthermore, Islamy (2004: 33-34) defines state policy as what the government claims to do or not do. The country's policies are the goals or objectives of government programs. 


\section{Policy stages}

The stages of public policy are as follows (Dunn, 1998 in Winarno, 2016: 32):

1. Agenda Compilation Stage

The elected and appointed officials place the issue on the public agenda. Previously these issues had competed first to get onto the policy agenda. In the end, several issues landed on the policy makers' policy agenda. At this stage, a problem may not be touched at all, while another problem is set to be the focus of discussion, or there may be a problem for some reason being postponed for a long time.

2. Policy Formulation Stage

Policymakers then discuss issues that have entered the policy agenda. These problems are defined and then look for the best solution to the problem. Solutions to these problems come from various existing alternatives or policy options. Similar to the struggle for a problem to enter the policy agenda, in the policy formulation stage, each alternative competes to be selected as a policy taken to solve the problem. At this stage, each actor will "play" to propose the best solution to the problem.

3. Policy Adoption Stage

Of the many policy alternatives offered by policymakers, in the end one of the policy alternatives was adopted with the support of the legislative majority, consensus between agency directors or judicial decisions.

4. Policy Implementation Stage

A policy program will only become an elite note if the program is not implemented. Therefore, the policy program decisions that have been taken as an alternative to solving the problem must be implemented, that is, implemented by administrative bodies and government agencies at lower levels. Administrative units that mobilize financial and human resources implement the policies that have been taken. At this stage of implementation, various interests will compete with each other. Some policy implementations have the support of implementers, but the implementers may oppose some others.

5. Policy Evaluation Stage

At this stage, the policies that have been implemented will be assessed or evaluated to see to what extent the policies made have been able to solve the problem. Public policy is basically made to achieve the desired impact. In this case, solve problems facing society. Therefore, measures or criteria are determined, which are the basis for assessing whether a public policy has achieved the desired impact.

\section{Policy implementation}

In this study, an implementation study is a form of study that contributes to the implementation phase of a policy. Policies are complicated to implement, and this difficulty is frequently political because of the interference of various interests. The authors, Daniel Mazmanian and Paul Sabatier, define policy implementation as the implementation of basic policy decisions, such as laws, but can also take the form of important executive orders or decisions or judicial decisions. In practice, the decision identifies the problem to be solved, defines the goals or objectives to be achieved, and describes the various approaches for implementing the plan. In the meantime, Van Meter and Van Horn (1975: 272) define policy implementation, which is one or more actions taken by individuals, officials, governments, or groups (public or private) toward the goals outlined in the policy decision. From the three definitions above, it can be seen that policy implementation involves three things, namely: (1) the existence of policy objectives or targets; (2) the existence of activities or activities to achieve goals; and (3) activity results.

Meanwhile, according to Soenarko (2005: 180), in implementing public policy, there are several provisions that must be fulfilled and carried out in order to succeed. These provisions concern the Authority of the implementer, the content of the policy, the legitimacy of the people and others. In the process of implementing policies or administering each program, there may be many actors involved in determining choices regarding the allocation of certain public sources as well as many parties who may try hard to influence these decisions (Wahab, 2008: 194), while Keban (2014: 76) states that an 
implementation deals with various activities directed at the realization of the program, in this case the administrator manages to organize, interpret and implement the policies that have been selected.

Based on this description, it can be concluded that implementation is a dynamic process in which the policy implementer carries out an activity or activity so that in the end, it will get an outcome that is in accordance with the objectives or objectives of the policy itself. This is in accordance with what was expressed by Lester and Stewart (2000: 104) where they say that implementation is a process and an output. The success of a policy implementation can be measured or seen from the process and the achievement of the end result (output), namely: whether the goals to be achieved are or not.

\section{George Edward's policy implementation model}

According to Edward III (1980: 21), there are four factors that influence policy implementation working simultaneously and interacting with each other to help or hinder policy implementation, so the ideal approach is to reflect on this complexity by discussing all these factors at once, namely:

1. Communication

In general, Edward III discusses three important things in the policy communication process, namely:

a) Transmission

To initiate a decision's execution, the official must first be informed that a decision has been reached and an order has been given for its implementation. And though it seems a simple operation, it can not be straightforward. These decisions are often disregarded even if they are not; there is a general misconception of the decisions given.

b) Clarity

If policies are implemented as desired, implementation instructions must not only be accepted by policy implementers, but policy communication must also be clear.

c) Consistency

The effectiveness of policy implementation depends on policy implementation orders being clear and comprehensive. Despite having a degree of consistency in the instructions given to implementers of policies, if the orders are mutually conflicting, then implementers of policies would not be able to properly carry out their duties.

\section{Resource}

The resources needed to implement policies include:

a) Staff

Employing large numbers of employees does not always guarantee an efficient implementation. This is attributable to the fact that public sector workers lack the necessary expertise, but the shortage of manpower would generate significant complications in the successful application of policies. People working on the project must have the expertise to carry out the job. Without adequately qualified staff, enforcing policies that cover a number of changes would be made difficult.

b) Information

The information takes two forms-first, information about how to implement a policy. Implementers need to know what to do and how they should do it. Thus, policy implementers must be given instructions for implementing the policy. Second, data on the compliance of other personnel with government regulations.

c) Authority

These powers will vary from program to program and take many different forms, such as the right to issue summons to appear in court; bring problems to court; issue orders to other officials; withdraw funds from a program; providing funding, staffing and technical assistance to local governments; buy goods and services, or collect taxes.

d) Amenities

To execute a plan effectively, an implementer would require appropriate personnel who comprehend the mission at hand and the Authority to carry it out. If they do not have an office like this to promote communication, they will not be able to successfully implement their plans. 


\section{Disposition}

If implementers display a specific policy courtesy, and this translates into support, they are more likely to bring the policy into effect as the decision-makers intended. Conversely, if the behavioral or decision-making opinions of the implementers vary from those of the decision-makers, implementing a policy becomes increasingly difficult.

\section{Bureaucratic Structure}

One of the most common institutions to bring proposals into motion is the bureaucracy. Bureaucracy can intentionally or unconsciously choose organizational forms in order to solve modern life's social problems. They are not only present in governmental systems but in other private entities, particularly educational institutions, and even a bureaucratic framework may be developed for the specific purpose of enforcing a certain policy.

\section{Van Meter \& Van Horn Policy Implementation Model}

There are six variables, according to Van Meter \& Van Horn (1975: 463) known as A Model of The Policy Implementation, which affect the performance of public policy implementation.

1. Size and Policy Objectives

The level of success of policy implementation can be measured if and only if the size and objectives of the policies are realistic with the socio-culture that exists at the level of policy implementers. When policy measures or policy objectives are too ideal (even too utopian) to be implemented at the citizen level, it will be difficult to realize public policy to the point where it can be said to be successful.

2. Resource

The success of the policy implementation process is highly dependent on the ability to utilize available resources. Humans are the most important resource in determining a successful implementation process. Certain stages of the entire implementation process require qualified human resources in accordance with the work required by policies that have been determined apolitically. But when the competence and capabilities of these resources are nil, then the performance of public policies is very difficult to expect. But apart from human resources, other resources that need to be taken into account are also financial and time resources. This is because inevitably when competent and capable amnesia resources are available and disbursement of funds through the budget is not available, problems will arise in realizing what the policy objectives are trying to achieve. Likewise, with time resources. When human resources are active and the disbursement of funds is tight, this can also be the cause of the unsuccessful implementation of policies.

3. Implementing Agent Characteristics

Public policies to be implemented would include formal organizations and informal organizations, all of which will collaborate to enforce those policies. To put it another way, the consistency of public policy implementation would depend significantly on the characteristics of the implementing agencies that are acceptable and consistent with the policy. For example, in the implementation of public policies that seek to radically change human behavior, the project executing agent must have the characteristics of being firm, tough, and strict in implementing the rules in accordance with the established legal sanctions. In addition, the scope or area of policy implementation needs to be taken into account when determining the implementing agency. The wider the scope of policy implementation, the greater the agents involved should be.

4. Attitude or tendency (Disposition) of the implementers

The attitude of acceptance or rejection of the implementing (agent) will greatly affect the success or failure of the performance of public policy implementation. This is possible because the policies implemented are not the result of the formulation of local residents who are very familiar with the problems and problems they feel. However, the policies that will be implemented by the implementers are 'top down' policies, which make it possible for decision-makers to never know (even be unable to touch) the needs, wants, or problems that citizens want to solve. 
5. Communication between organizations and implementing activities

Coordination is a mechanism as well as the main condition in determining the success of policy implementation. The better the coordination and communication between the parties involved in an implementation process, the more likely it is that errors will occur, and vice versa.

6. Economic, Social, and Political Environment

The last thing that needs to be considered in order to assess the performance of public implementation from the perspective offered by van Metter \& van Horn is the extent to which the external environment contributes to the success of the established public policies. The environment in question includes the social, economic, and political environment, and an environment that is not conducive to being the culprit for the failure of the performance of policy implementation. Therefore, efforts to implement policies must also pay attention to the conducive conditions of the external environment.

Based on the description of using the implementation model above eating in analyzing research problems, the authors use a combination of George C. Edward III (1980) policy implementation model with four variables and Van Metter \& Van Horn (1975) policy implementation model with two variables, as follows: Size and Policy Objectives, Communication, Resources, Disposition, Bureaucratic Structure, and Economic, Social, Political Environment.

\section{Fostering families of Indonesian Workers/Bina Keluarga Tenaga Kerja Indonesia (BKTKI)}

The legal basis for the formation of Indonesian Migrant Workers' Family Development is Law No.18 of 2017 concerning the Protection of Indonesian Migrant Workers, Regulation of the Minister of Women's Empowerment and Child Protection Number 20 of 2010 concerning General Guidelines for Family Development of Indonesian Workers (TKI) and Technical Guidelines for Implementing Family Development Policies TKI, and the Mayor's Decree No. Kupang. 114 B / KEP / HK / 2017 concerning the Establishment of a Working Group (POKJA) for Family Development of Indonesian Workers in Kupang City.

Fostering a TKI family is very necessary considering that the objective conditions of the TKI family are philosophically, sociologically and economically disadvantaged. This condition is getting stronger by looking at the fact that the development of Indonesian migrant workers and their families tends to be left behind even though there is an increase in the economy, but the sustainability of their economic conditions, conditions of household harmony and the growth and development of their children still need the attention of various parties. Moreover, the development of information technology, the existence of globalization as well as the emergence of new life phenomena such as consumptive culture, instant culture affects socio-economic conditions in general.

The strategies implemented by the Kupang City Government in implementing BKTKI policies are: First, formulating policies (laws and regulations, implementing guidelines (operational guidelines), general guidelines, technical guidelines, and standard operating procedure (SOP). Second, information communication and education (IEC), socialization, counseling, media campaigns, dialogue, workshop. Third, coordination and cooperation with the government, private sector and the community. Fourth, facilitation in the form of provision of funds, human resources, facilities, infrastructure and training. Fifth, the formation of Pokja and BKTKI groups (up to the village level).

The efforts made by the local government, in this case, the City Government of Kupang, are: First, forming a City Level BKTKI Working Group, with members from cross-regional work units (SKPD), the business world and the community. Second, forming the Village BKTKI Group (Currently 6 Kelurahan). Third, the integration of SKPD policies/programs/activities into the BKTKI Policy framework (the role of Bappeda in planning coordination). Fourth, the integration of the BKTKI Group as part of the existing target group programs in the regions: Improving the Quality of Life of Women (PKHP), Bina Joint Groups (BKB), Joint Business Groups (KUB), Child-Friendly Cities (KLA), Cooperatives, Women's Economic Enterprises (UEP), Productive Migrant Villages, and so on. 
In connection with the implementation of the BKTKI policy, there are three activities carried out by the Women Empowerment and Child Protection Agency, namely as follows:

1. Workshop, which is an activity carried out directly by The Ministry Of Women's Empowerment And Child Protection regarding the introduction of the BKTKI program as well as the launching of the BKTKI program in Kupang City as a pilot project throughout Indonesia in May 2017. After this activity, it continues to provide material about the BKTKI program by the Head of The Ministry Of Women's Empowerment And Child Protection Office to the families of TKI from each of the six sub-districts (Naimata, Fatululi, Nefonaik, Namosain, Batuplat, and Lasiana) which became the working group for the BKTKI program and delivered material on the Indonesian Migrant Workers (PMI) law. This activity was held twice, namely in April 2018 and May 2019. This activity was attended by 30 people with each representative from each village. The purpose of this activity is to invite the families of TKI to participate actively participating in the BKTKI program in order to have an effective impact on the lives of the TKI family. On the other hand, the workshop was carried out "sharing experiences" by the former TKI community with the TKI family about the lives of the migrant workers to meet their family needs. The goal is that the families of TKI can properly manage the money they send from their family members who become migrant workers.

2. Institutional Strengthening, namely in the form of socialization activities for the provision of material on child protection laws, as well as training on parenting. Provides knowledge about parenting styles for children, especially children of TKI who are cared for by other family members such as grandparents, uncle and tanta. Parenting activities are intended so that children of migrant workers who are entrusted to their family members receive fair treatment and are entitled to a proper education. This parenting activity was carried out in 2019 directly by The Ministry Of Women's Empowerment And Child Protection with the Kupang City Office of The Ministry Of Women's Empowerment And Child Protection as the facilitator of the activity, at the Kanaan Naimata church attended by 30 families and children of TKI from each urban village.

3. Joint Business Group (KUB), namely the formation of joint business groups in each of the six subdistricts that become the BKTKI working group and provide assistance in the form of funds to each group running their business. In 2018 there was no provision of funding for group business development. In 2019, assistance in the form of business capital was provided by the Women's Protection sector in collaboration with the field of improving the quality of life for women (PKHP). The accountability report from KUB is in the form of a spending note as evidence. Regarding the provision of assistance in the form of goods, the Kupang City Office of The Ministry Of Women's Empowerment And Child Protection has collaborated with the Kupang City Agriculture Office, the Kupang City Marine and Fisheries Service, the Kupang City Animal Husbandry Service, and other related agencies. The need for goods assistance from KUB makes a proposal in the form of what is needed, and then the assistance is processed by the relevant agency. The people involved in the TKI family development group belong to the TKI family and the common people (non-former TKI housewives). Types of business of each village, namely: Naimata Village: raising pigs, vegetables, weaving. Kelurahan Fatululi: vegetables, weaving, making organic fertilizers. Kelurahan Nefonaik: vegetables, kiosk, making plastic flowers. Namosain Village: fishermen group (fish). Batuplat Village: Sewing. Lasiana Village: fishermen group (fish). These types of business activities are then carried out by each member of the TKI family development group. Of the types of businesses above, there are businesses that are run individually, such as kiosk businesses, weaving, sewing, and selling fish. The result of their efforts becomes the fulfillment of the needs of the family. Meanwhile, the results of the group business are divided among each active group member, and part of it is saved as capital for the group to develop their business.

\section{Research methodology}

This research uses a qualitative research method, which employs a case study approach. Case study analysis is a qualitative research methodology whose researchers analyze real-life, current situations or multiple scenarios through comprehensive and in-depth data collection that involves a range of sources of knowledge, and findings in case descriptions and themes. A compound case is an alternative to a single case in a case analysis (in-site study) (Creswell, 2015: 135-136). 


\section{Results and discussions}

The implementation model used by researchers in this study is a combination of George C. Edward III's policy implementation model with four variables and the van Metter \& van Horn policy implementation model with two variables, as follows: Policy Size and Purpose, Communication, Resources, Disposition, Structure Bureaucracy, and Economic, Social, Political Environment.

\section{Size and objectives of Indonesian Workers' Family Development Policy (BKTKI)}

This variable is based on the main importance of the factors that determine policy performance.

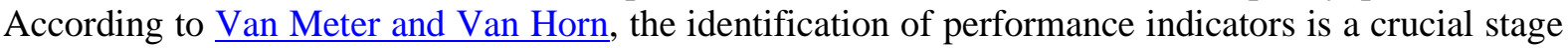
in the analysis of policy implementation. These performance indicators assess the extent to which basic measures and policy objectives have been realized. Basic measures and objectives are useful in describing the objectives of the policy decision as a whole.

Size and policy objectives based on the Regulation of the Minister of Women's Empowerment and Child Protection No. 20/2010 concerning BKTKI's General Guidelines that Indonesian workers who work abroad who leave their families are vulnerable to economic problems, family harmony and affect the development of their children so that guidance is needed for the families of TKI. In the stages of preparation, implementation, and monitoring and evaluation, the preparatory stage includes facilitation, outreach, and advocacy on the need for the development of the TKI family, seeking agreement and forming a working group (government and community) which is tasked with compiling an action plan and forming family groups of TKI that will be given guidance. The implementation stages include the efforts made by each member of the working group in implementing BKTKI programs and activities that are their responsibility. The monitoring and evaluation phase is carried out by the BKTKI working group to oversee the implementation of programs and activities of working group members by providing guidance to fix and overcome obstacles or obstacles.

The size and purpose of the BKTKI policy are realized by the Kupang City Government, in this case, THE MINISTRY OF WOMEN'S EMPOWERMENT AND CHILD PROTECTION Office on the Protection of Women with three forms of activities, namely Workshop, Institutional Strengthening and Joint Business Group. In terms of size and policy objectives of the BKTKI, as explained by the Head of Kupang City Office of The Ministry Of Women's Empowerment And Child Protection and the Head of the Section for the Protection of Women Workers and Trafficking in Persons in the previous description that the regulations from the Minister of Women's Empowerment and Child Protection regarding BKTKI policies have a positive effect on the people of Kupang City as efforts to improve the economic quality of the families of former migrant workers. This is evidenced by the involvement of 6 (six) Village in Kupang City in the formation of TKI family development groups with a business development pattern that is being carried out by group members, and the involvement of former and non-ex-TKI housewives who have become members of the TKI family development group in activities held both from the Kupang City Office of The Ministry Of Women's Empowerment And Child Protection and from the Minister of Women's Empowerment and Child Protection.

According to Van Meter \& Van Horn (in Agustino, 2016: 133) known as A Model of Policy Implementation affects the performance of public policy implementation. The level of success of policy implementation can be measured if and only if the size and objectives of the policies are realistic with the socio-culture that exists at the level of policy implementers. When policy measures or policy objectives are too ideal (even too utopian) to be implemented at the citizen level, it will be difficult to realize public policy to the point where it can be said to be successful.

Based on the results of research on the size sub-focus and policy objectives according to the theory put forward by Van Meter and Van Horn regarding the size and objectives of these policies, the findings of researchers related to the implementation of BKTKI policies carried out by the Kupang City Office of The Ministry Of Women's Empowerment And Child Protection in the Sector of 
Women's Protection have been implemented according to the objectives policies and support existing theories.

\section{Communication}

Communication is a very important factor because communication is related to the delivery of information, ideas, regulations and others using certain means to those who are entitled to receive them (Arifin, 2003: 5). Communication is one of the benchmarks to see the extent to which policies or regulations in this case, the family development policy of Indonesian workers must be conveyed clearly so that there is the same interpretation and can be carried out consistently by the implementers at various levels consisting of:

\section{Transmission}

The first factor put forward by Edwards that has an effect on policy communication is the transmission. To initiate a decision's execution, the official must first be informed that a decision has been reached and an order has been given for its implementation. And though it seems a simple operation, it cannot be straightforward. These decisions are often disregarded even if they are not; there is a general misconception of the decisions given.

The Kupang City Government, in this case the Kupang City Office of The Ministry Of Women's Empowerment And Child Protection in implementing the Family Development policy for Indonesian Workers, is based on the Regulation issued by the State Minister for Women's Empowerment and Child Protection of the Republic of Indonesia Number 20 of 2010 concerning General Guidelines for Family Development for Indonesian Workers Application of Family Development Policy for Indonesian Workers. The implementation of BKTKI policies realized by the Kupang City Government, in this case, the Kupang City Office of The Ministry Of Women's Empowerment And Child Protection on the Protection of Women, is in accordance with the BKTKI policy objectives, namely, economic empowerment, family resilience and welfare, and child protection. By forming a working group that includes elements of the Kupang City Government as stipulated in the Decree of the Mayor of Kupang Number 114B / KEP / HK / 2017, as well as forming family groups of TKI in six sub-districts who will be given guidance.

The Kupang City Office of The Ministry Of Women's Empowerment And Child Protection through the Women's Protection Sector is guided by the rules issued by the Minister of The Ministry Of Women's Empowerment And Child Protection No. 20 of 2020 and also always carry out coordination in building good communication between the Head of the Office and Staff in the Field of Women's Protection in order to realize good implementation for the people of Kota Kupang, especially former TKI, especially for female workers.

\section{Clarity}

The second factor that Edwards points out is clarity. If policies are implemented as desired, policy implementers must not only accept implementation instructions, but policy communication must also be clear.

Regarding the technical instructions for implementing the TKI family development policy, which is contained in the regulation of the Minister of Women's Empowerment and Child Protection Minister of Women's Empowerment and Child Protection No. 20/2010, provides detailed instructions on the implementation of BKTKI activities from the preparation stage to monitoring and evaluation and emphasizes the need for assistance in the field in implementing the TKI family development policy. The implementation of the TKI family development policy can be implemented more easily and can run well, and each operator in the region has the same perception in implementing the said activity effectively and efficiently, which officials from the Kupang City Office of The Ministry Of Women's Empowerment And Child Protection always build good communication regarding clarity in policy implementation foster families of TKI.

The communication pattern between the Kupang City Office of The Ministry Of Women's Empowerment And Child Protection and the Village as an element of the government that brings 
together the community to join the TKI family development group is well established. So that various programmed activities can run well, and the expected results from these activities can improve people's mindsets and ways of developing their businesses.

\section{Consistency}

With uneven policy enforcement, implementers may administer policy leniently. If this occurs, so unsuccessful policy enforcement is a foregone conclusion. In implementing the TKI family development policy, the Kupang City Office of The Ministry Of Women's Empowerment And Child Protection, both the Head of the Office and Staff for the Protection of Women in order to follow up the Regulation of the Minister of Women's Empowerment and Child Protection No. 20/2010, all decisions regarding the implementation of the TKI family development program are always held by internal meetings of the heads of offices and staff in the field of women's protection. This is done so that all forms of activities that support the TKI family development program can run consistently without any conflicts during implementation later. Communication must be well established so that the clear purpose of program implementation is always directed and can be understood by the implementing agency.

Based on the results of research on the communication sub-focus, related to two factors, namely transmission and clarity according to the theory put forward by George C. Edwards regarding the policy communication, that the findings of researchers related to communication in the implementation of BKTKI policies carried out by the Kupang City Office of The Ministry Of Women's Empowerment And Child Protection in the Protection Sector Women have been implemented according to policy and supported the existing theory. Meanwhile, in terms of consistency of policy communication by the implementation of the TKI family development policy, the Kupang City Office of The Ministry Of Women's Empowerment And Child Protection has not been well realized, which results in the ineffectiveness of the implementation of the policy.

\section{Resource}

Implementation orders may be passed on carefully, clearly, and consistently, but if implementers lack the necessary resources to implement policies, then implementation tends to be ineffective. These resources include:

\section{Staff}

With regard to the aspect of human resource availability, it becomes one of the important things in every policy implementation within the Kupang City Government, especially in the Kupang City Office of The Ministry Of Women's Empowerment And Child Protection in the Field of Protection of Women as the implementer of the TKI Family Development policy, because without adequate human resources all the matters of implementation policies cannot run optimally.

The number of resources for civil servants and non-permanent staff in the Women's Protection Sector in Kupang City based on gender and class is sufficient, namely 3 men and 3 women. It's just that there was a vacancy in the Head of the Division that was transferred on December 9, 2019.

\section{Finance}

The implementation of the TKI family development policy by the policy implementer is in the field of Protection of Women with the activity budget in accordance with the Budget Implementation Document (DPA). The funds for the business development of the TKI family development group for which the Women's Protection sector is not available, which causes the sustainability of the group's business to not run well. The strategic step taken by the women's protection sector is to coordinate with the field of improving the quality of life of women (PKHP), in which there is a group business development fund for the 2019 fiscal year. With the assistance of business development funds, it is given temporarily to one business group, namely Naimata Village. Due to a deficit in a pure budget, it is necessary to rationalize the budget for all OPDs, so that every woman's business group can get business development fund assistance. 


\section{Information}

Information related to the family development policy of Indonesian Migrant Workers within the scope of the Kupang City Office of The Ministry Of Women's Empowerment And Child Protection in implementing internal policies at the office has discussed in detail the process of implementing the policy. With the aim that all staff in the field of Women's Protection understand and interpret the implementation of these policies both in terms of legal rules, procedures, benefits, and goals and objectives for the realization of the economic welfare of the families of ex-Indonesian Migrant Workers.

\section{Authority}

The Authority is given by the head of the Kupang City Office of The Ministry Of Women's Empowerment, and Child Protection to the Women's Protection Sector as the implementer of the TKI family development policy affects the implementation of this policy. Such Authority is such as issuing orders to hold meetings to discuss the implementation of the TKI family development policy so that it runs according to procedures and achieves the expected results.

\section{Facilities}

The availability of resources, namely staff, information, Authority and facilities at the Kupang City Office of The Ministry Of Women's Empowerment And Child Protection, especially in the Protection Sector, is sufficient to support the implementation of the duties and functions of the employees. Sufficient staff to carry out the TKI family development policy, the information provided properly to understand and translate the implementation of policies, directed Authority, and available facilities to meet the needs of employees so as to make it easier for policy implementers to carry out their duties.

\section{Disposition}

\section{Impact Of Disposition}

The behavioral trends or characteristics of policy implementers play an important role in realizing the implementation of policies that are in accordance with the goals or objectives. From the results of the study, it was found that the attitude of the implementers in implementing BKTKI policies at the Kupang City Office of The Ministry Of Women's Empowerment And Child Protection, the Sector of Women's Protection was running well.

\section{Appointment of Bureaucrats}

The results showed that the appointment of bureaucrats experienced by the Kupang City Office of The Ministry Of Women's Empowerment And Child Protection in the Field of Women's Protection in implementing the policy of Indonesia Migrant Workers Family Development is no obstacles because the policy has been implemented well.

\section{Multiple Incentives}

Incentives obtained by staff in the field of women's protection as the implementer of the Indonesian Migrant Workers family development policy are in the form of People's Welfare and Official Travel Letter with a budget based on the 2018 Budget Implementation Document (DPA), with details including official travel expenditures (within and outside the region) Rp. 33,710,000, -, spending on work services Rp. 2,750,000, -. And the 2019 fiscal year with details, among others: official travel expenditure (inside and outside the region) Rp. 56,500,000, -, work service expenditure of Rp. $2,600,000$, - . The incentives provided are a motivating factor for the staff implementing the Indonesian Migrant Workers family development policy to carry out orders properly. This is done as an effort to fulfill the personalities of the staff in the field of women's protection to support their performance.

\section{Bureaucratic structure}

Effect of Organizational Structure for Implementation of Standard Operating Procedures (SOP)

The bureaucratic structure that is owned in implementing BKTKI policies is well available by the Regional Government. It means that the bureaucratic structure is available starting from the highest level, namely the central, provincial, to the lowest level, namely districts / cities. 


\section{Fragmentation}

The bureaucratic structure also has an influence on the implementation of Indonesian Migrant Workers family development policies, namely the SOP set by the Kupang City Office of The Ministry Of Women's Empowerment And Child Protection helps and facilitates the field of Women's Protection as the implementer of the policy activities of Indonesian Migrant Workers family development in carrying out various activities that have been planned and agreed upon. In its implementation, as a form of responsibility, the activity has been carried out, the activity implementer, namely the Women's Protection sector, makes an accountability report to the head of the department as the person in charge of the activity.

\section{Economic, social and political environment}

The economic and social environment supports the implementation of Indonesian Migrant Workers family development policies, seen from the funding of activities that come directly from the Kupang City Budget and collaborating with private institutions that support the implementation of Indonesian Migrant Workers family development policy in Kupang City. However, various problems also felt by group members in six villages. Their business groups are running in moderation, and some have not even started from the very beginning. Of course, economic factors such as business development funds become obstacles for group members to run their businesses. On the other hand, political conditions also do not contribute in the form of financial assistance for the former migrant workers who want to run their businesses. Of course, all government and private parties need to pay more attention to the economic survival of the migrant workers' families by providing financial assistance to develop their businesses. Meanwhile, the agency does not receive any form of support from the political parties to participate in the implementation of the Indonesian Migrant Workers family development policy. Various political interests will influence the implementation of this policy. Thus, the economic, social and political environment influences the implementation of the migrant worker family development policy.

\section{Conclusion}

Based on the results of the previous research and discussion, it can be concluded that the size and objectives of the implementation of the Indonesian Migrant Workers family development policy, namely the implementation of Workshop, Institutional Strengthening, and Joint Business Group activities carried out by the Kupang City Office of The Ministry Of Women's Empowerment And Child Protection in accordance with the aims and objectives of implementing the family development policy targeting the former Indonesian Migrant Workers community that was formed in family development groups of Indonesian Migrant Workers from six villages in Kupang City. Communication on the implementation of the Indonesian Migrant Workers family development policy by means of transmission and clarity goes well through the coordination and communication of the implementation of the Indonesian Migrant Workers family development policy, and the availability of human resources, information, Authority, and facilities that support the implementation of Indonesian Migrant Workers family building policies. The impact of the disposition is the commitment to implementing policies to carry out programs and activities related to the Indonesian Migrant Workers family development policy, and some incentives to encourage staff morale in implementing the policy.

\section{Limitation and study forward}

This research only analyzes the existing policies in Kupang City. Similar policies can have different results due to different conditions faced. There are still other variables that may influence the Indonesian migrant workers' families' development policies in Indonesia. Further research will be very useful to add information that is lacking in this study. 


\section{References}

Agustino Leo. (2008). Dasar-dasar kebijakan publik. Bandung: Alfabeta.

Anderson, James. (1984). Publik policy making. New York, Holt, Rinehart and Winston.

Arifin, Anwar.(2003). Komunikasi Politik: Paradigma Teori Aplikasi Strategi Komunikasi Politik Indonesia. Jakarta: Balai Pustaka

Creswell, John W. (2015). Penelitian kualitatif \& desain riset. Yogyakarta : Pustaka Pelajar.

Edward III, George C. (1980). Implementing public policy. Washington: Congressional Quarterly Press

Friedrich, Carl. (1969). Man and his government. New York, McGraw-Hill.

Islamy, M. Irfan. (2004). Prinsip-prinsip Perumusan Kebijaksanaan Negara. Jakarta: Bumi Aksara.

Keban, Yeremias T. 2014. Enam dimensi startegis administrasi publik, konsep, teori dan isu.Yogyakarta: Gavamedia.

Lester, James P. dan Joseph Stewart. 2000. Public policy: an evolutionary approach (second edition). Australia: Wadsworth.

Mulyadi Deddy. (2016). Studi kebijakan publik dan pelayanan publik: Konsep dan aplikasi proses kebijakan publik berbasis analisis bukti untuk pelayanan publik. Bandung: Alfabeta.

Pemerintah Daerah Kota Kupang. (2017). Surat Keputusan Walikota Kupang No. 114 B / KEP / HK / 2017 tentang Pembentukan Kelompok Kerja (POKJA) Pengembangan Keluarga Tenaga Kerja Indonesia di Kota Kupang. Pemerintah Daerah Kota Kupang.

Pemerintah Republik Indonesia. (2017). Undang-Undang Nomor 18 Tahun 2017 tentang Perlindungan Pekerja Migran Indonesia. Lembaran Negara Tahun 2017 Nomor 242. Sekertariat Negara. Jakarta.

Pemerintah Republik Indonesia. (2010). Peraturan Menteri Pemberdayaan Perempuan dan Perlindungan Anak Nomor 20 Tahun 2010 tentang Pedoman Umum Pembinaan Keluarga Tenaga Kerja Indonesia (TKI) dan Pedoman Teknis Pelaksanaan Kebijakan Pembinaan Keluarga TKI. Kementrian Pemberdayaan Perempuan dan Perlindungan Anak. Jakarta.

Pemerintah Republik Indonesia. (2010). Peraturan Menteri Pemberdayaan Perempuan dan Perlindungan Anak Nomor 20 Tahun 2010 tentang Pedoman Umum BKTKI. Kementrian Pemberdayaan Perempuan dan Perlindungan Anak. Jakarta.

Pemerintah Republik Indonesia. (2009). Undang-Undang 52 Tahun 2009 tentang Perkembangan Kependudukan dan Pembangunan Keluarga. Lembaran Negara Republik Indonesia Tahun 2009 Nomor 161. Sekertariat Negara. Jakarta.

Soenarko. 2005. Public Policy: Pengertian Pokok untuk Memahami dan Analisa Kebijaksanaan Pemerintah. Surabaya : Airlangga University Press.

Van Meter, Donald S \& Van Horn, Carl E. (1975). The Policy Implementation. Process: A Concentual Framework in: Administration and Society v, 6(4), 445-485.

Wahab, Solichin Abdul. (2008). Analisis kebijaksanaan dari formulasi ke implementasi kebijaksanaan negara. Jakarta : Bumi Aksara.

Winarno Budi. (2016). Kebijakan Publik Era Globalisasi: Teori, Proses, dan Studi Kasus Komparatif. Yogyakarta: CAPS. 